УДК 311:504.4

Рацлав В.В., к.т.н., доцент, докторант

Донбаської державної машинобудівної академії

\title{
ОЦІКАА ЯКОСТІ 3 ПРОБЛЕМАМИ ЕКОЛОГІЧНОГО ТА ЕКОНОМІЧНОГО ВИКОРИСТАННЯ ПОВЕРХНЕВИХ ВОД БАСЕЙНУ РІЧКИ СІВЕРСЬКИЙ ДІНЕЦЬ
}

\begin{abstract}
Здійснено статистичний аналіз проблем екологічного й економічного використання водних ресурсів Донбасу з метою поліпшення екологічної ситуації, зроблено спробу визначити можливість інтегрованого планування управління басейном річки Сіверський Дінець, що сприятиме прийняттю екологічних та економічних зважених оперативних і стратегічних рішень, які призведуть до поліпшення екологічної ситуації в Україні.

Ключові слова: інтегроване управління, водні ресурси, водопостачання, водокористування, стічні води, водоресурс, антропогенне навантаження, водоресурсний потенціал України, геоінформаційні системи.
\end{abstract}

Volodymyr R.

\section{QUALITY ASSESSMENT WITH THE PROBLEMS OF ENVIRONMENTAL AND ECONOMIC USE OF SURFACE WATERS OF THE SEVERSKY DONETS BASIN OF THE RIVER}

The statistic analysis of the problems of ecological and economic use of Donbas water resources with the aim of improving the ecological situation, was fulfilled; the attempt to define the possibilities of planning the integrated management of river Sivers'kyi Donets basin, was made. It would surely contribute to the adoption of ecologically and economically considered operative and strategic decisions and lead to the improvement of ecological situation in the country.

Key words: integrated management, water resources, water supply, water use, sewage, anthropogenic loading, water-resourceful potential of Ukraine, geoinformative systems.

Рацлав В.В.

\section{ОЦЕНКА КАЧЕСТВА С ПРОБЛЕМАМИ ЭКОЛОГИЧЕСКОГО И ЭКОНОМИЧЕСКОГО ИСПОЛЬЗОВАНИЯ ПОВЕРХНОСТНЫХ ВОД БАССЕЙНА РЕКИ СЕВЕРСКИЙ ДОНЕЦ}

\begin{abstract}
Осуществлен статистический анализ проблем экологического и экономического использования водных ресурсов Донбасса с целью улучшения экологической ситуации, сделана попытка определить возможность интегрированного планирования системы управления бассейном Северского Донца, что будет способствовать принятию экологических и экономических взвешенных оперативных и стратегических решений, направленных на улучшение экологической ситуации в стране.

Ключевые слова: интегральное управление, водные ресурсы, водоснабжение, водопользование, сточные воды, водоресурсы, антропогенная нагрузка, водоресурсний потенциал Украины, геоинформационные системы.

Постановка проблеми у загальному вигляді i ï̈ зв'язок 3 важливими науковими та практичними завданнями. Донбас невідворотно вибрав шлях сталого, екологічно безпечного та комфортного соціально - економічного розвитку регіону. Стратегія регіонального розвитку Донбасу передбачає рівнозначимість його соціальної, економічної та екологічної складових. I сьогодні, незважаючи на військовий конфлікт на сході України, як ніколи, потрібна зважена та розсудлива державна політика щодо
\end{abstract}


ефективного використання природних ресурсів, їх збереження для забезпечення спроможності та збалансованого розвитку об'єднаних територіальних громад. Оцінка стану довкілля в Донецькій та Луганській областях свідчить, що практично немає природних компонентів екосистеми, які б не зазнавали постійного негативного антропогенного впливу. 3 одного боку, екологічна ситуація в області загалом задовільна, екологічні показники життєдіяльності відповідають допустимим нормам, ніж в більшості інших регіонів країни і значно кращі, ніж в середньому по Україні. Це обумовлює визначення Донбасу як досить сприятливого регіону для проживання та роботи. 3 іншого боку можна зазначити, що в Донецькій і Луганських областях наявні екологічні ризики і проблеми щодо стану поверхневих водних об'єктів та підземних вод, земель та лісів. Рівень забруднень навколишнього середовища в області не $\epsilon$ катастрофічною, але наявні екологічні ризики і проблеми, при умові ефективної i цілеспрямованої роботи в цьому напрямку, можуть бути суттєво зменшені. На території Донбасу постійно та неухильно реалізується соціальна політика яка спрямована на збереження безпечного для існування живої та неживої природи навколишнього середовища. В значній частці забезпечується захист життя і здоров'я населення від негативного впливу, зумовленого забрудненням навколишнього природного середовища, для досягнення гармонійної взаємодії суспільства і природи, охорони, використання і відтворення природних ресурсів.

Моніторинг якості стану довкілля, поверхневих та підземних вод є складовою частиною системи державного моніторингу довкілля та ключовим елементом Плану управління річковим басейном на всіх етапах його розробки - від визначення референційних умов і сучасного стану водних об'єктів з метою складання переліку необхідних заходів для досягнення «доброго» стану водних об'єктів до контролю реалізації запланованих водоохоронних заходів, згідно з принципами Водної Рамкової Директиви ЕС та Постанови Кабінету Міністрів України від 18.05.2017 № 336 «Про затвердження порядку розроблення плану управління річковим басейном» [2,17].

Басейн річки Сіверський Дінець є важливішою та головною водною артерією сходу України, що забезпечує потреби у воді населення,сільське господарство та промисловий комплекс Луганської, Донецької та Харківської областей. Суббасейн Сіверського Дінця згідно з прийнятим гідрографічним районуванням у межах України - це унікальна екологічна система, що відзначається складним водогосподарським комплексом зі значним різноманіттям ландшафтів на унікальній території, де розташований національний парк «Святі Гори», в якому знаходяться унікальні види рослин та тварин. Стан довкілля річки є важливішим водним ресурсом Донбасу - найбільш техногенно навантаженого регіону України.

Загальна площа басейну річки Сіверський Дінець - 98,9 тис.км2, зокрема й на території України - 54,5 тис.км2. Довжина річки становить 1053км, по Україні 723км, 3 яких у Харківській області - 375км, Донецькій - 95км, Луганській - 253км.

Сіверський Дінець має розгалужену мережу приток, серед яких: 11 середніх та 247 малих річок. У басейні нараховується 679 озер (площа водного дзеркала - 5620га), 149 водосховищ загальним об'ємом 1997,1 млн. м3, два канали (довжиною 263км і 131.6км) і 5 великих водоводів, а також 2679 ставків (загальним об'ємом 295.9млн.м3).

Військовий конфлікт на сході України призвів до цілої низки небезпечних подій та наслідків:

- забруднення довкілля і впливів на грунти та ландшафти;

- погіршення стану поверхневих і підземних вод;

- надання шкоди рослинному і тваринному світу. 
За час конфлікту неодноразово відзначено порушення водопостачання та водовідведення на території Донбасу, які супроводжувались скидами забруднювальних речовин у басейни річок та водосховищ. Результати проведених досліджень СіверськоДонецьким басейновим управлінням водних ресурсів (БУВР) показали підвищенні концентрації азоту й фосфору у воді річок Сіверський Дінець, Клебан-Бик, Кальміус, Бахмутка і Кальміус [3,12].

На замовлення Управління ООН із координації гуманітарних питань (УКГП ООН) швейцарські фахівці провели польову оперативну експрес-оцінку небезпеки можливих аварій уздовж лінії зіткнення та комплексний аналіз стану діяльності компанії «Води Донбасу» і джерел ризику щодо водопостачання регіону [4,23 ].

Моніторинг якісного стану поверхневих водних об'єктів басейну р. Сіверський Дінець здійснюється Сіверсько-Донецьким БУВР у межах державної системи моніторингу довкілля. Екологічний стан поверхневих вод у створах річки на основі інтегрального показника якості води відносяться переважно до III класу якості 4 категорії (задовільні, слабо забруднені), II клас якості 3 категорії (добрі, досить чисті) відзначаються лише у верхів 'ї у створах на межі Бєлгородської та Харківської областей та Печенізькому водосховищі. Найбільш забрудненими притоками є річки Казенний Торець і Бахмутка (Донецька область), Верхня Біленька і Нижня Біленька (Луганська область), які відповідають III класу як 5 категорія (посередні, помірно забруднені).

Критична екологічна ситуація на території, яка межує 3 непідконтрольною територією, яка все далі стає катастрофічною. Через закриття та підтоплення шахт, що використовуються як сховища відходів, вибухи боєприпасів та використання військової техніки забруднюється не лише грунт, але й водні ресурси. Постала проблема забруднення поверхневих та підземних вод, які є водними ресурсами не тільки Донбасу, а і країни в цілому.

За оцінкою експертів у 2017 році, на запит Міністерства екології та природних ресурсів Україна Координатор проектів ОБСЄ в Україні розпочав проект «Визначення шкоди, заподіяної довкіллю на сході України», завданнями якого стали моніторинг впливу конфлікту на природне середовище. У зв'язку з прийняттям постанови Кабінету Міністрів від 19.09.2018 №758 «Про затвердження Порядку здійснення державного моніторингу вод» 31 січня 2019 року встановлюються нові вимоги до організації здійснення державного моніторингу вод, взаємодії центральних органів виконавчої влади в процесі його здійснення та забезпечення органів державної влади й органів місцевого самоврядування інформацією для прийняття рішень щодо стану вод.

Несприятлива обстановка, що склалася в галузі водовикористання та водопостачання, пов'язана із цілим комплексом питань, що мають місце на всіх стадіях водогосподарської діяльності: забору води з природних водних джерел, втрати води під час транспортування, а також упровадження заходів щодо запобігання шкідливої дії поверхневих і підземних вод, захисту водних ресурсів тощо. За таких умов, особливого значення набуває проблема не лише екологічного та економічного використання водних ресурсів, а й планомірного та інтегрованого управління водним басейном річки Сіверський Дінець.

Аналіз останніх досліджень, у яких започатковано вирішення проблеми. Проблеми ефективного державного управління водними ресурсами, природокористуванням та охороною природного середовища досліджувались у наукових працях М. Хвесика, В. Голяна, Б.Данилишина, С. Дорогунцова, І. Драгана, Т. Іванової, В. Сташука, А. Яцика, О.Яроцької, Т. Клауссена та інших. Питаннями управління водними ресурсами басейну р. Сіверський Дінець займається СіверськоДонецьке БУВР, перед яким стоять основні завдання: 
- управління річковим басейном та експлуатація водогосподарськогомеліоративного комплексу в Донецькій області;

- соціально-економічний розвиток річкового басейну;

- охорона й екологічне оздоровлення річкового басейну та механізми їх фінансування;

- упровадження інтегрованого плану в управлінні водними ресурсами регіону.

Цілі статті - виявлення теоретичних методологічних положень щодо інтегрованого державного управління водними ресурсами регіону, здійснити статистичний аналіз проблем екологічного й економічного використання поверхневих водних ресурсів Донбасу з метою поліпшення екологічної ситуації, зробити спробу визначити можливість інтегрованого планування управління басейном річки Сіверський Дінець, що сприятиме прийняттю екологічних та економічних зважених оперативних і стратегічних рішень, які призведуть до поліпшення екологічної ситуації в Україні.

Мета державного інтегрованого управління водними ресурсами пов'язана із забезпеченням координованого розвитку та управлінням водними, земельними та іншими ресурсами, щоб здійснити результативність економічного, соціального i екологічного благополуччя на рівноправній, збалансованій основі без завдання шкоди життєво найважливішим природним екосистемам Донбасу. Враховуючи результати моніторингу з питань якості та кількості водних ресурсів, впровадження заходів для вирішання аспектів водного менеджменту, матимуть позитивний вплив на екосистеми в басейні річки Сіверський Дінець .

Виклад основного матеріалу дослідження 3 повним обгрунтуванням отриманих наукових результатів. Військовий конфлікт на сході України призвів до цілого ряду небезпечних явищ, що створили екологічні та економічні проблеми при використанні водних ресурсів Донбасу, але в останні роки негативні явища можуть призвести до непоправних наслідків. Небезпечний рівень забруднення водних ресурсів Донецької та Луганської областей пов'язаний із великим об'ємом стічних вод, кількість яких біля 700 млн. куб. м щорічно скидається в річки регіону. В останні часи за вмісту значної частки мінералізації та іонів тяжких металів такі води непридатні для питного та технічного водопостачання. Для попередження масштабної катастрофи необхідно ввести екологічний, економічний, політичний та інші принципи контролю і регулювання щодо охорони та відтворення водних запасів. Проведення державного моніторингу якості води басейну річки Сіверський Дінець для оцінки тисків, спричинених гідроморфологічних змін, застосовуються як методологію для створення Плану управління басейну, на основі важливого аспекту водного менеджменту (ВАМП). Для кожного ВАВМ, які для кількості водних ресурсів, необхідно буде визначити три важливих аспекти:

- забруднення органічними та неорганічними речовинами;

• виявити поживні та небезпечні сполуки;

- гідроморфологічні зміни басейну.

Щоб адаптувати управлінські цілі к басейну річки Сіверський Дінець до аспектів ВАМП, необхідно розробити бачення та управлінські цілі щодо питань якості й кількості води, а саме:

- описати заходи, які вживатимуться для скорочення чи припинення наявних істотних тисків у масштабі басейну і суббасейнів для кожного ВАМП і підземних вод;

- покращити зв'язок між заходами на державному рівні та координації на басейновому та суббасейному рівнях для досягнення загальних природоохоронних цілей водній рамковій директиві (ВРД). 


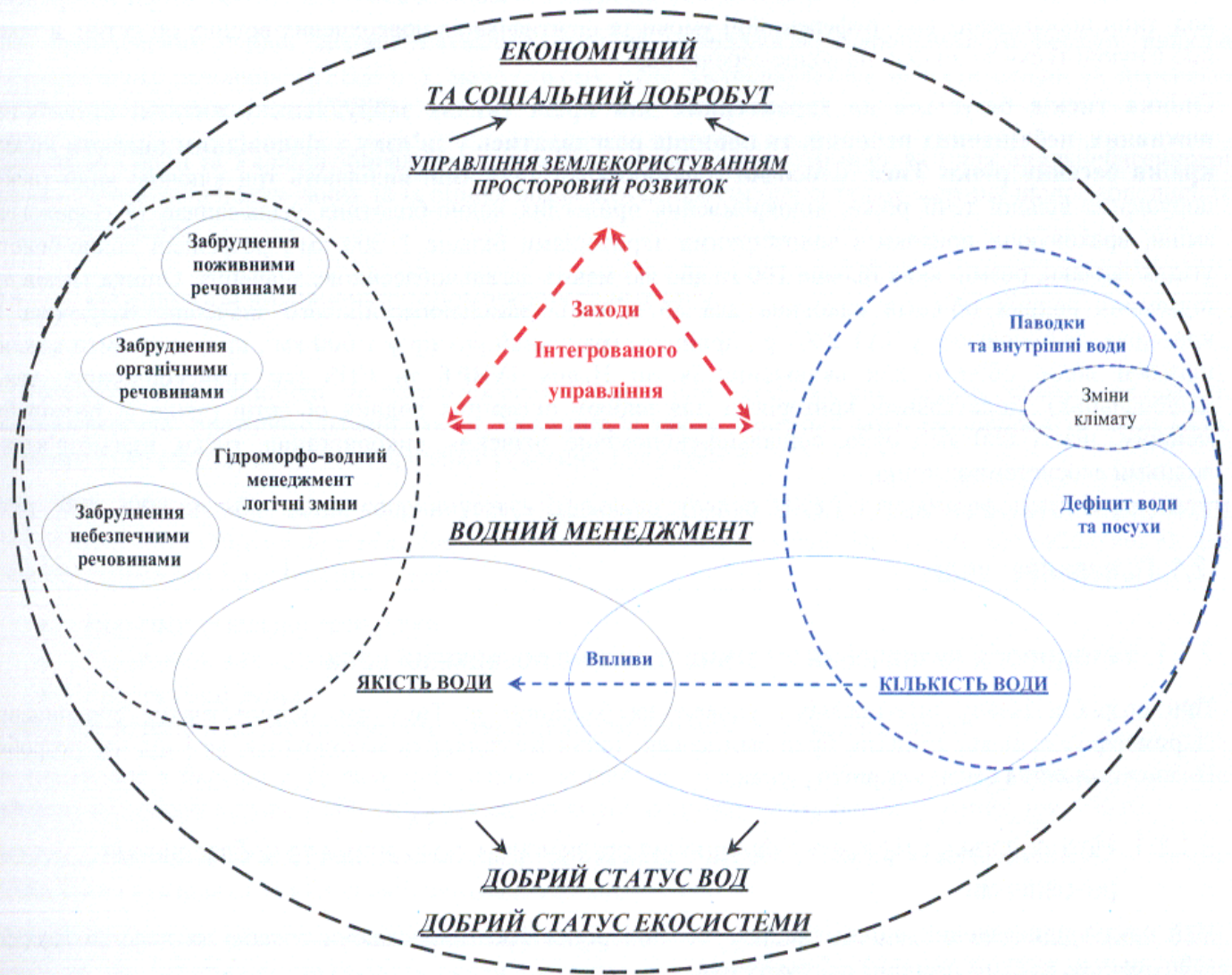

Рис.1 Взаємозв'язки між якісним та кількісним аспектами водного менеджменту $[7,19]$.

За запасами водних ресурсів басейн Сіверського Дінця є маловодним регіоном, де забезпеченість потреби у воді утричі менша, ніж у цілому по Україні. Водночас, це один iз найбільш навантажених серед основних річкових басейнів держави. Саме тому першочергове значення має відповідальне водокористування, охорона й відтворення водних ресурсів басейну Дінця та річок Донбаського регіону. Для цього необхідна повна статистична інформація про стан водних ресурсів. Водний кодекс передбачає державний облік водокористування поверхневих і підземних вод. Облік та аналіз стану поверхневих водних ресурсів здійснюється через подання водокористувачами до державних органів водного господарства звітів про водокористування за встановленою формою. Водокористуванням і водовідведенням займається статистика водних ресурсів, яка $\epsilon$ частиною екологічної статистики. Об'єктами статистики є:

- водокористувачі водних джерел;

- використання води підземних горизонтів;

- зворотні (стічні) води.

Така статистична інформація збиралася за даними Сіверсько-Донецького басейного управління водних ресурсів державного обліку водокористування за формою 2ТП-водгосп. У 2017 році до поверхневих водних об’ єктів басейну р. Сіверський Дінець здійснювали скид 173 підприємства, усього було скинуто 412,6 млн.м ${ }^{3}$ зворотних вод. Найбільший об’єм скиду здійснюється до басейну р. Уди 193,7 млн.м (47\% від загального по басейну), русла р. Сіверський Дінець - 95,15 млн.м ${ }^{3}$ (23\%) та басейну p. Казенний Торець - 86,97 млн.м ${ }^{3}(21 \%)$. 
У цілому по басейну основний відсоток скиду стічних вод здійснюється КБО «Диканівський» та «Безлюдівський» (КП «Харківводоканал» очисні споруди м. Харкова) - 138,92 та 51,03 млн.м ${ }^{3}$ відповідно (46 \% від загального по басейну). Відповідно до цього частка скиду сольових показників (сухий залишок) цих підприємств у загальному скиді складає $66 \%$.

Зауважимо, що з 2016 року підприємства, які здійснюють скид шахтно-кар'єрних вод, надають звіт без урахування інгредієнтів, тому визначити вплив цих підприємств, зокрема й вугільної промисловості, на якісний стан водних об’єктів неможливо.

\section{Сольові показники та жорсткість}

\section{Сульфати}
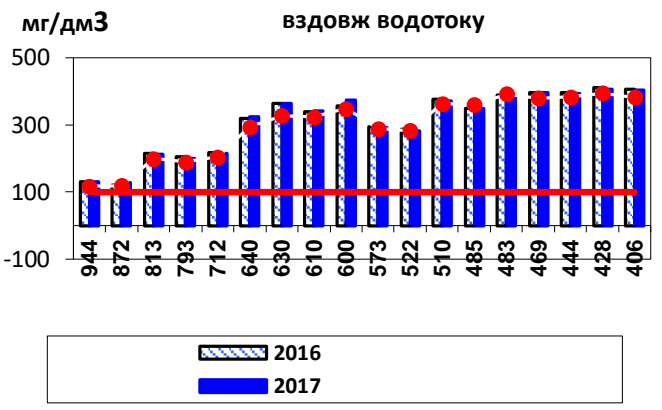

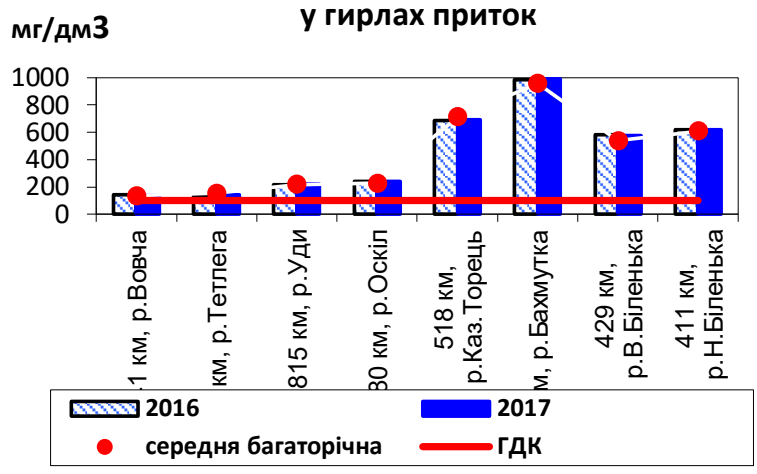

\section{Хлориди}

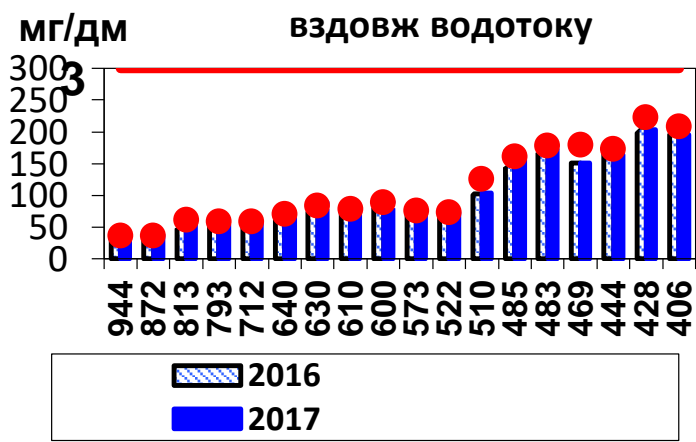

\section{Мінералізація (сухий залишок)}
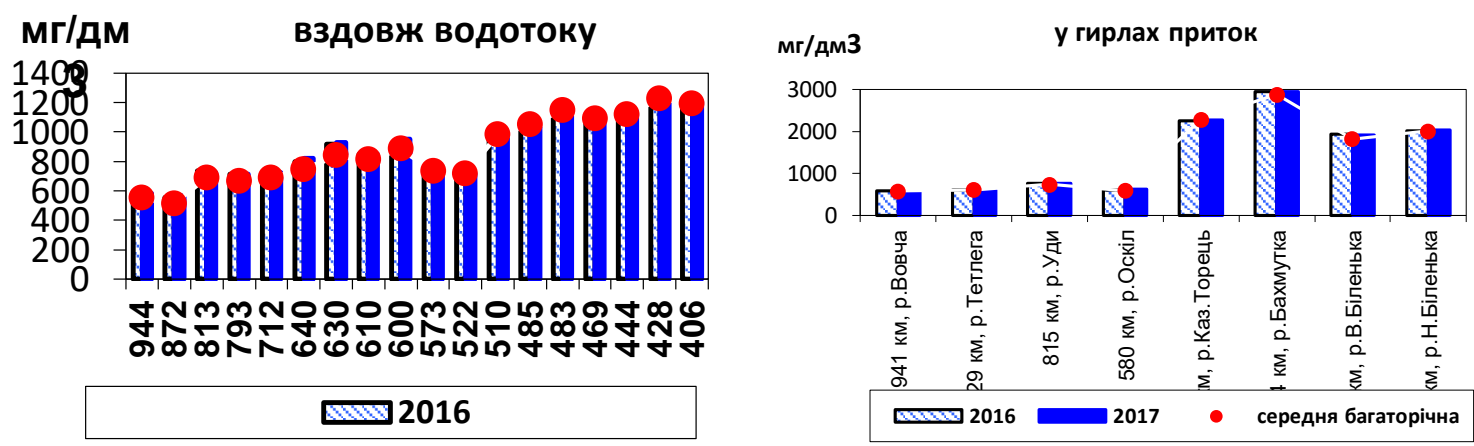
Жорсткість

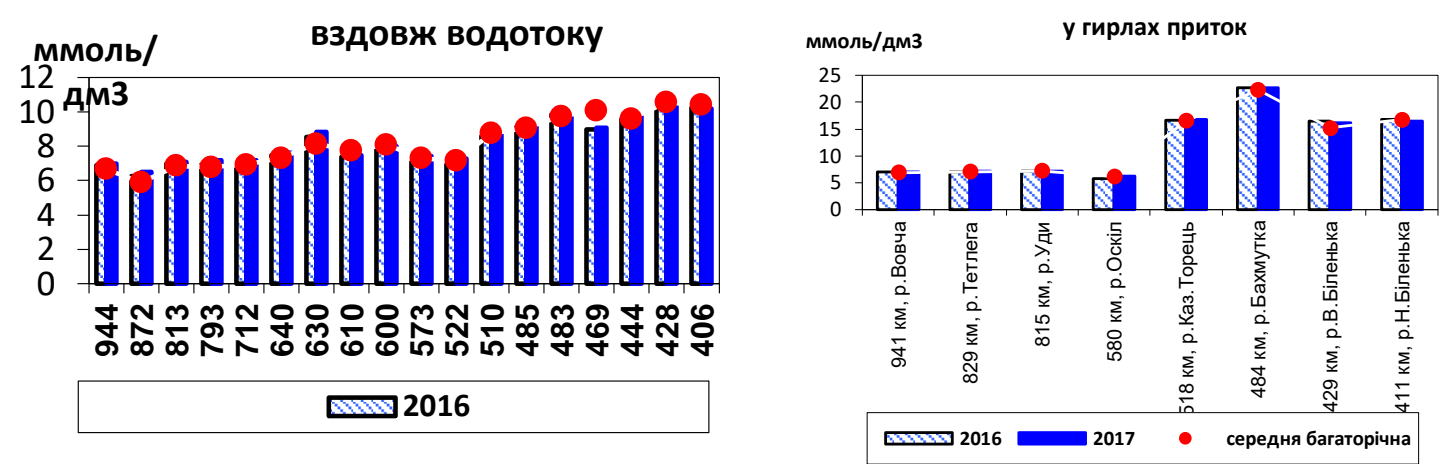

Органічні показники

\section{БCK-5}
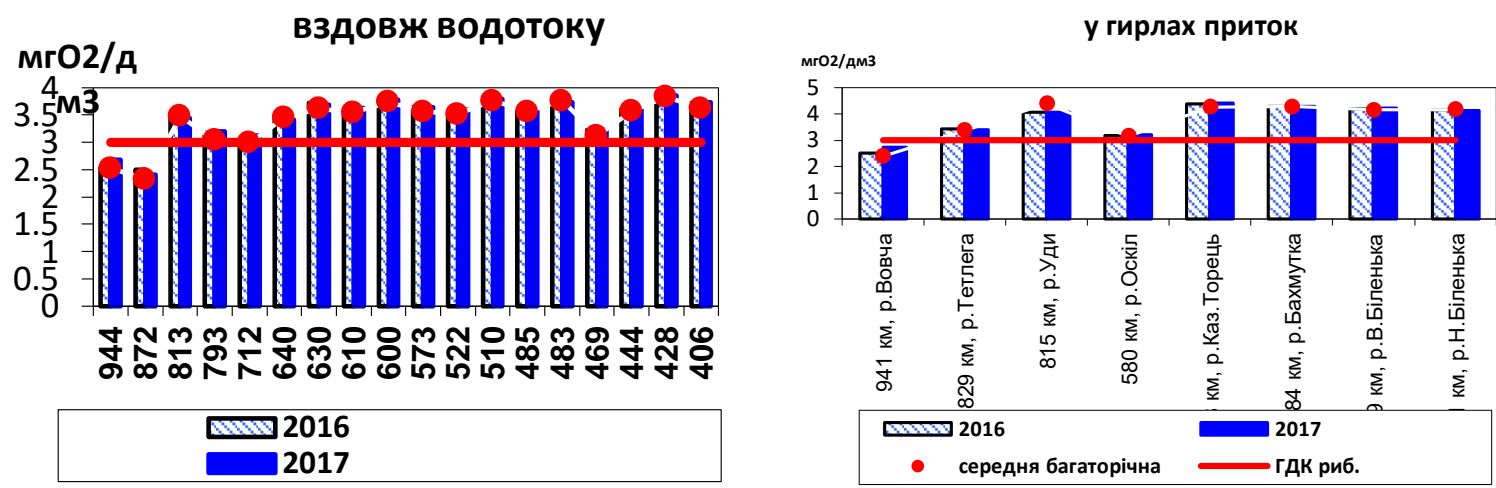

XCK
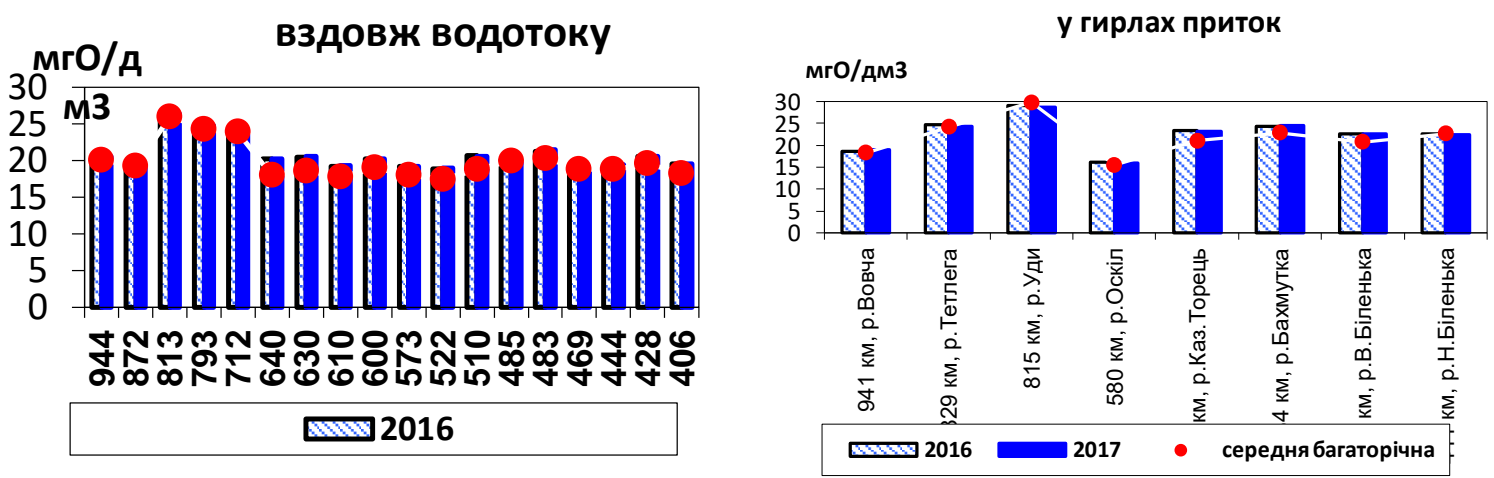

\section{Нафтопродукти}
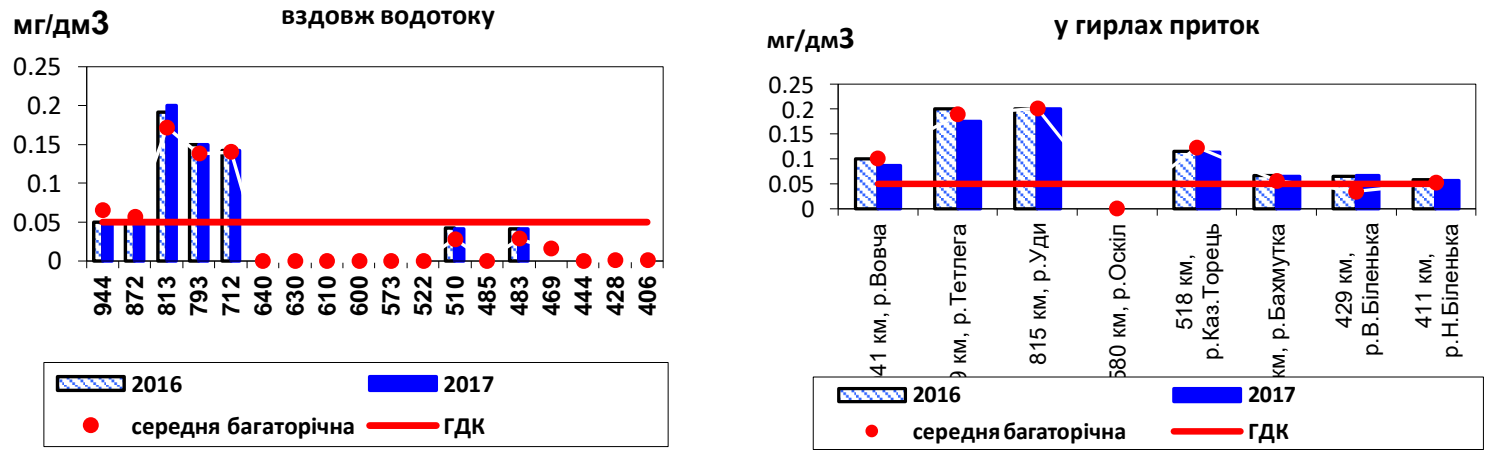
У 2017 році вздовж водотоку р. Сіверський Дінець концентрація органічних показників варіює по БСК 5 щодо ГДК від 0,8 до 1,3 ; у гирлах приток від 0,9 до 1,5. Підвищений уміст органічних речовин у поверхневих водних об'єктах басейну пов'язаний з активною господарською діяльністю та скидом забруднених стічних та зворотних вод. Помічаємо перевищення концентрацій нафтопродуктів у створах нижче впадіння р. Уди - 2,8-4 ГДК та у гирлах приток 1,1-4 ГДК.

Концентрації органічних речовин в усіх пунктах спостережень уздовж водотоку p. Сіверський Дінець та в гирлах основних приток майже на рівні минулого року (коливання в межах 0,1-6\%) та незначно варіює в межах середньо багаторічних значень. За даними державного обліку водокористування, за формою 2ТП-водгосп до поверхневих водних об'єктів басейну було скинуто 131,3 тис.т органічних речовин (за ХСК), найбільший скид здійснюється до басейну р. Уди - $73 \%$, басейну р. Казенний Торець - 12 \% та русла р. Сіверський Дінець - $10 \%$. У цілому концентрація біогенних речовин майже на рівні попереднього року (коливання в межах 0,3-10\%) та середньо багаторічних значень. Уміст біогенних речовин значно підвищується після впадіння р. Уди, що пов'язано зі скидами з очисних споруд м. Харкова КП «Харківводоканал» (КБО «Безлюдівський та «Диканівський»). За даними державного обліку водокористування, за формою 2ТП-водгосп цими підприємствами скидається 75\% біогенних речовин від загального скиду по басейну [2].

Ще гірші справи в південній частині Донецької області, куди воду постачають по каналу Сіверський Донець-Донбас. Свіжа вода 3 каналу використовується підприємствами металургійної та вугільної промисловості, енергетики та комунального господарства. Основна частина забруднень доводиться на річки Приазов'я, де скидання забруднень складає понад 20 відсотків. Використання значних обсягів водних ресурсів на виробничі потреби, неякісне очищення каналізаційних стоків та сільськогосподарські відходи - це все заподіює невиправну шкоду водним ресурсам Донбасу. Наслідки забруднення води надзвичайно шкідливі для людини, тоді як головним чинником забруднення $\epsilon$ людино-антропогенний чинник. За тим, як забруднюються річки, найбільше виділяються річки Кальміус, Казенний Торець, Самара, Солона, Бик та Вовча. Попри зменшення об'ємів водоспоживання останні роки (порівняно з 1990 р. - удвічі) інтенсивність використання водних ресурсів у Донецькій області залишається найбільшою по Україні. На жаль, суспільство недооцінює негативні наслідки змін якості та кількості показників водних ресурсів.

Економічні проблеми водних ресурсів свідчать про те, що необхідно розв'язати безліч питань комплексного використання водних ресурсів: упровадження оптимальних норм витрати води, упровадження прогресивних технологічних процесів виробництва та прогресивних систем очищення стічних вод, опріснення мінералізованих вод, відтворення запасів прісних підземних вод, витягання корисних компонентів зі стічних вод і низку інших питань ефективного використання водних ресурсів - тому для цього необхідно зробити план інтегрованого управління басейном річки Сіверський Донець, проведення постійного державного моніторингу якості води басейну для оцінки тисків, спричинених гідро морфологічними змінами, на основі водного менеджменту. У зв'язку з екологічною ситуацією, що склалася в області та в цілому по Україні, пріоритетними напрямками з поліпшення стану водних ресурсів Донецької області є:

$\checkmark$ зменшення негативних наслідків під час закриття шахт, а також фільтрації шкідливих речовин у шахтах, що діють;

$\checkmark$ демінералізація шахтних вод;

$\checkmark$ будівництво систем зливової каналізації з очищенням поверхневого стоку 3 території міст і виробничих промислових майданчиків, постачання виробничих стічних вод;

$\checkmark$ розчищення малих річок і водойм області;

$\checkmark$ упорядковування водозахисних зон прибережних захисних смуг. 
3 метою охорони й раціонального використання водних ресурсів у довгостроковій перспективі було прийнято Програму науково-технічного розвитку Донецької області на період до 2020 г, у якій передбачено:

$\checkmark$ здійснити оцінку сучасного стану прогнозних ресурсів й експлуатаційних запасів підземних питних вод Донецької області з виявленням джерел забруднення;

$\checkmark$ здійснити будівництво й реконструкцію наявних очисних споруд промислових, господарчо-побутових стоків і каналізаційних ліній;

$\checkmark$ забезпечити впровадження у виробництво передових світових маловодних технологій, систем повторного використання стічних вод;

$\checkmark$ здійснити перехід на замкнуті системи водопостачання технологічних процесів;

$\checkmark$ забезпечити розробку і впровадження новітніх технологій із розширення використання мінералізованих підземних і шахтних вод на технологічні потреби;

$\checkmark$ удосконалити технологічні процеси на виробництві;

$\checkmark$ здійснити розробку дієвих заходів із недопущення аварійних ситуацій.

Розв'язати проблему оптимального управління водогосподарським комплексом, можливо, через системну реалізацію державної політики в галузі водного господарства, використання ресурсів держави та регіонів із метою забезпечення інноваційноінвестиційного розвитку водного господарства, що уможливить підвищення ефективності державного управління водними ресурсами на регіональному рівні $[4,8]$. Ураховуючи вищевикладене, реалізацію заходів пропонують упровадити через:

- удосконалення нормативно-правової бази щодо забезпечення інноваційного та інвестиційного розвитку водного господарства на регіональному рівні;

- упровадження ефективного, обгрунтованого та збалансованого механізму використання, охорони та відтворення водних ресурсів, забезпечення сталого розвитку регіональної системи моніторингу довкілля, зокрема й водних ресурсів;

- підвищення технологічного рівня водокористування, упровадження маловодних та безводних технологій, розроблення більш раціональних нормативів водокористування, будівництва, реконструкції та модернізації систем водопостачання та водовідведення;

- удосконалення стандартів і нормативів щодо використання водних ресурсів та лімітів забору води й скидання забруднювальних речовин у водні об'єкти та прямого водо обліку й технології розподілу води на водогосподарських системах;

- реалізації водо та енергозберігальних технологій, які забезпечать підвищення функціонування водогосподарського комплексу.

Висновки. Виконання запропонованих заходів уможливить:

$\checkmark$ задовольнити потребу населення та галузей економіки в якісних водних pecypcax;

$\checkmark$ зменшити обсяг споживання та відведення води;

$\checkmark$ забезпечити ефективний захист територій та населення від шкідливої дії вод;

$\checkmark$ удосконалити галузеву структуру водокористування, насамперед, у комунальному господарстві, хімічній промисловості;

$\checkmark$ знизити рівень водоємності промислового виробництва;

$\checkmark$ підвищити ефективність та забезпечити екологічну безпеку водокористування.

3 метою поліпшення екологічної ситуації на Донбасі необхідно вжити науково обгрунтовані заходи, які повинні завершуватись їх реалізацією на практиці. На цьому етапі дуже важливим буде їх обговорення на басейнових і міжвідомчих радах із залученням обласних i районних державних адміністрацій, органів місцевого самоврядування, територіальних органів міністерств та відомств, водокористувачів, наукових закладів та громадських організацій. Така практична взаємодія дасть змогу ще на етапі інтегрованого планування усунути низку непорозумінь методичного й прикладного характеру.

Список використаних джерел: 
1. Загальнодержавна цільова програма розвитку водного господарства та екологічного оздоровлення басейну річки Дніпро на період до 2021 року [Електронний ресурс] : Закон України від 24.05.2012 p. № 4836-VI. - Режим доступу : http://zakon4.rada.gov.ua.

2. Бідоцерківська Н.О., Сидоренко І.В. Якісний аналіз вод басейну р. Сіверський Донець за гідрохімічними показниками / Водне господарство.-2018. №5. 50с.

3. Сіверський Донець: Басейн Здоров'я - людям життя! Київ,ВАITE,2018.-30с.

4. Оцінка екологічної шкоди та пріоритети відновлення довкілля на сході України.-К.:ВАITE,2017.-88c.

5. Водний Кодекс України [Електронний ресурс] // ВВР України. - 1995. - № 213/95.

6. Вострікова Н. В. Аналіз стану законодавчої бази щодо інтегрованого управління водними ресурсами в Україні / Н. Вострікова // Державне будівництво. - 2014. - № 1. - С. 45-50.

7. План інтегрованого управління басейном річки Тиса: Міжнародна комісія із захисту річки Дунай / www.icpdr/org.$\underline{122 \mathrm{c}}$.

Рецензент д.е.н., професор Матвійчук Л.Ю.

УДК 332.122:504

Рудь Н.Т., д.е.н., професор

Гура О. С., магістрант

Луцький національний технічний університет

\section{ЯКІСНЕ СПОЖИВАННЯ ТА РАЦІОНАЛЬНЕ ВИКОРИСТАННЯ ВОДНИХ PECУРСIВ}

У статті відзначено стратегічне значення питання водопостачання для України. Систематизовано сучасні проблеми водопостачання. Вказана соціальна значущість водопровідної води питної якості. Показано необхідність нової логіки побудови відносин між постачальником та споживачами. Розроблена система заходів, що сприятимуть покращанню соціально-економічних умов водопостачання.

Ключові слова: питна вода, споживання, використання, економічний збиток, здоров'я, водопостачання.

Рудь Н. Т., Гура О. С.

\section{КАЧЕСТВЕННОЕ ПОТРЕБЛЕНИЯ И РАЦИОНАЛЬНОЕ ИСПОЛЬЗОВАНИЕ ВОДНЫХ РЕСУРСОВ}

В статье отмечено стратегическое значение вопроса водоснабжения для Украины. Систематизированы современные проблемы водоснабжения. Указана социальная значимость водопроводной воды питьевого качества. Показана необходимость новой логики построения отношений между поставщиком и потребителями. Разработана система мер, способствующих улучшению социальноэкономических условий водоснабжения.

Ключевые слова: питьевая вода, потребление, использование, экономический ущерб, здоровье, водоснабжение.

Rud N., Gura O.

\section{QUALITY CONSUMPTION AND RATIONAL USE OF WATER RESOURCES}

В статье отмечено стратегическое значение вопроса водоснабжения для Украины. Систематизированы современные проблемы водоснабжения. Указана социальная значимость водопроводной воды питьевого качества. Показана необходимость новой логики построения отношений между поставщиком и потребителями. Разработана система мер, способствующих улучшению социальноэкономических условий водоснабжения.

Ключевые слова: питьевая вода, потребление, использование, экономический ущерб, здоровье, водоснабжение.

Keywords: drinking water, consumption, use, economic damage, health, water supply.

Постановка проблеми у загальному вигляді i iï зв'язок 3 важливими науковими та практичними завданнями. Постачання житлового фонду 